\title{
Pollution Indices as a Tool for the Assessment of Heavy Metals in Soil of Automobile Workshops in Benin City
}

\author{
Bala Anegbe ${ }^{1 *} \quad$ James M Okuo $^{2} \quad$ Felix E Okieimen $^{3} \quad$ Endurance Idu ${ }^{4}$ \\ 1.Department of Basic and Industrial Chemistry, Western Delta University, P.M.B. 10, Oghara, Delta State \\ 2.Environmental Analytical Research Laboratory, Department of Chemistry, University of Benin, Benin City \\ 3.GeoEnvironmental and Climate Change, Department of Chemistry, University of Benin, Benin City \\ 4.Department of Chemistry, Delta State College of Education, Mosogar, Nigeria
}

\begin{abstract}
Soil contamination by heavy metals is increasing day by day. In this study, pollution indices which include geoaccumulation index (I-geo), enrichment factor (EF), environmental risk factor (ERF), contamination factor (CF), degree of contamination (CD), contamination/pollution index (C/PI) and pollution load index (PLI) among others were used. The City was divided into four zones; Northwest (NW), Northeast (NE), Southwest (SW) and Southeast (SE). The average total levels of heavy metals in soil samples analyzed in SE, SW, NE, NW and control were 143.1, 118.6, 129.1, 143.3 and $0.85 \mathrm{mg} / \mathrm{kg}$ respectively. The levels of Cd in soils from all the zones were greater than the target values. The results of the I-geo ranged between highly polluted to very highly polluted. The CF showed very high level of contamination for all the heavy metals in all the zones. The C/PI values were less than 1 (contamination range) for all the heavy metals in all zones except for $\mathrm{Cd}$ which was greater than 1 (pollution range) in all zones. The negative values of ERF recorded for all the metals in all zones implied that the heavy metals analyzed may present potential environmental threat. The PLI values were 331.08, 313.12, 287.54 and 313.86 for NW, NE, SW and SE respectively. This study revealed that automobile workshop is one of the major sources of anthropogenic soil pollution in Benin City and its environs.
\end{abstract}

Keywords: Automobile Workshop, Heavy Metals, Pollution Indices and Soil.

DOI: $10.7176 / \mathrm{CMR} / 12-4-04$

Publication date: April $30^{\text {th }} 2020$

\subsection{INTRODUCTION}

Soil contamination is an excess of any element or compound through direct or secondary exposure which causes toxic response from biota and/or humans resulting in unacceptable environmental risks (Vangronsveld et al. 2009). Contamination of soil with both organic and inorganic compounds is a worldwide problem that has been accentuated by industrialization, urbanization and intensive agriculture. Inorganic pollutants in soil are mainly heavy metals and come essentially from industrial activities: fuel combustion, mineral extraction and processing, vehicular exhaust and particulate emission, coal and fossil fuel combustion metal smelting, etc. Organic pollutants in soil include the listed priority organic pollutants (POPs), chlorinated hydrocarbon pesticides, polychlorobiphenyls, etc. Inorganic and organic pollutants can present a threat to human and ecological health through direct contact or can be a source of contaminant dispersal to groundwater and surface water resources and can hinder the ability of soil to support vegetation and a functioning ecosystem (Martin and Ruby, 2004). In the recent past, there have been increasing interests regarding heavy metal contaminations in the environments, apparently due to their toxicity and perceived persistency within the soil systems (Tijani et al. 2005). The most common heavy metals found in the contaminated sites are Cadmium, chromium, copper, lead, mercury, nickel and zinc. These heavy metals are one of the main sources of environmental pollution and affect the human health, life of animals (Mohanty and Mahindrakar, 2011). Heavy metal pollution of soil enhances plant uptake causing accumulation in plant tissues and eventual phytotoxicity and change of plant community (Gimmler et al. 2002). In environments with high nutrient levels, metal uptake can be inhibited because of complex formation between nutrient and metal ions (Gothberg et al. 2004).Various methods have been employed for the determination of the level of contamination in soils. The most common method is via total elemental analysis (USEPA method 3050) in which the level of contamination is expressed as mg metal kg-1 soil. The level of contamination may also be reported as leachable metal and determined by the toxicity characteristic leaching procedure (TCLP) (USEPA method 1311) or the synthetic precipitation leaching procedure (SPLP) (USEPA method 1312). The procedures measure the concentration of metals in leachate from soil contacted with an acetic acid solution (TCLP) or dilute solution of sulphuric acid and nitric acid (SPLP) (DPR-EGASPIN, 2002). This methods gives the total concentration of these metals is soils which passed very little information about the extent and degree of pollution. Thus this research aim at assessing of automechanic soil enriched with heavy metals using indices of pollution. The most common ones are the enrichment factor, environmental risk factor, geoaccumulation index, contamination factor, degree of contamination, pollution load index and contamination/pollution index been widely utilized as a measure of pollution in soil. Total concentrations and fractionation of metals in soil of the automechanic workshops have been documented by Anegbe et al. (2018). This study can be considered the first 
attempt to evaluate the heavy metals pollution in soil of the automechanic workshops in Benin City by using indices of pollution.

\subsection{MATERIALS AND METHODS}

\subsection{Study Area}

Benin is a transitory town and a fast growing City with a population of 1,147,188 according to 2006 population census. Benin City is the administrative capital of Edo State. Small-scale enterprises/artisan workshops dot the landscape of the City. Figure 1 shows map with three hundred and thirty-eight sampled automobile workshops. No waste management practice is done on these workshops. Wastes are indiscriminately discarded on the soils.

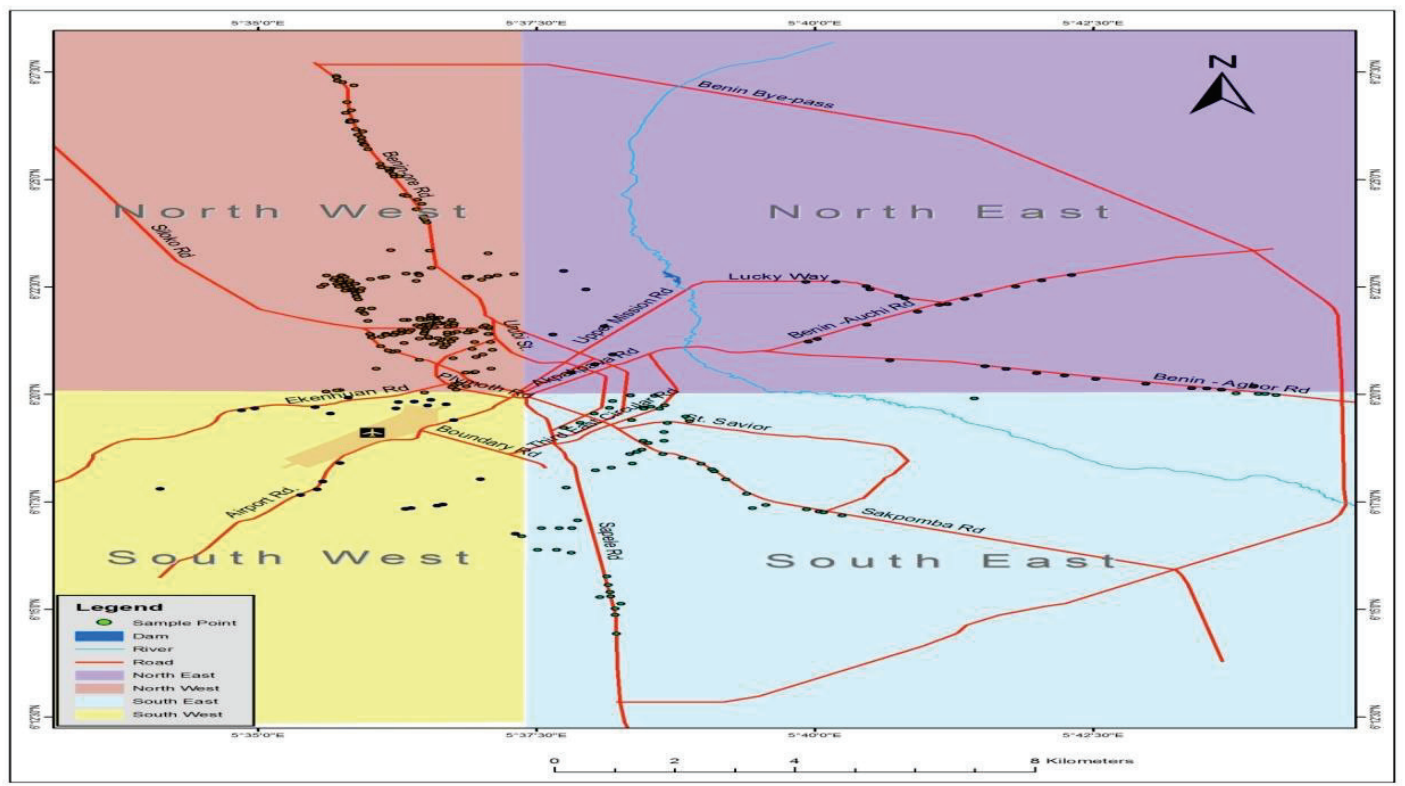

Fig. 1: Map with Three Hundred and Thirty-Eight Sampled Automobile Workshops.

\subsection{Soil Sampling Protocol and Preparation}

A survey carried out to enumerate automobile workshops in Benin City revealed five hundred and seven (507) active workshops in the metropolis. The City was divided into four zones; Northwest (NW), Northeast (NE), Southwest (SW) and Southeast (SE) to allow a closer examination of the activities within each workshop location in the zones. It was observed that i) a typical automobile workshop accommodated a variety of artisans; mechanics, panel-beater, battery-charger and spray-painter and ii) several semi-automobile workshops operated in clusters each specializing in one-or-more brands of vehicle: cars by brand and/or make, lorries by make etc. It was seldom to find a workshop with lorries and cars. On account of proximity of workshops, activities and duration of operation of the workshops, soil samples were taken from three hundred and thirty-eight (338) workshops. The number of samples to be analysed were further reduced to 40 in the NW zone, 15 in the SE zone, 10 each in the NE and SW zones based on the number of workshops in the zones and the cluster density of workshops in the zones. Top soil samples were collected at the epicentre of the automobile workshop and at a control site farmland in the Faculty of Agriculture, University of Benin. The standard chain of custody for handling soil samples was followed in the transfer of the samples to the laboratory. The soil samples were then air-dried, crushed/ground in a porcelain mortar and sieved through a $2 \mathrm{~mm}$ mesh. The soil samples with $<2 \mathrm{~mm}$ size were retained for analysis.

\subsection{Determination of the Heavy Metals in Soil Samples}

The pseudo-total levels of $\mathrm{Ni}, \mathrm{Cr}, \mathrm{V}, \mathrm{Fe}, \mathrm{Cd}$ and $\mathrm{Pb}$ in soil were extracted by acid digestion in accordance with the USEPA method described by Khodadoust et al. (2005). While fractionation was carried out as described by Anegbe et al. (2017)

\subsection{Soil Pollution Indices}

\subsubsection{Index of Geoaccumulation (Igeo)}

Index of geoaccumulation ( $\left.\mathrm{I}_{\mathrm{geo}}\right)$ was used to evaluate the heavy metal pollution by comparing current concentrations with reference (control) values as reported by Bentum et al. (2011).

$\mathbf{I}_{\text {geo }}=\log _{2} \frac{\mathrm{Cn}}{1.5 \mathrm{Bn}}$ 


\subsubsection{Environmental Risk Factor}

It is assessed from the fractionation of heavy metals to determine the labile and recalcitrant metal pools in the soil using the expression (Saenz et al. 2003; Lin et al. 2006)

$$
E R F=\frac{C S Q V-C_{i}}{C S Q V}--------(2)
$$

Where CSQV = Concentration of the soil quality value (heavy metal concentration in residual fraction of the soil (assumed to be equivalent to the background/pre-industrial concentration).

$\mathrm{Ci}=$ heavy metal concentration in the first three fractions in the soil.

\subsubsection{Enrichment Factor}

The extent of soils contamination was assessed using the enrichment factor (EF) (Woitke, 2003; Reddy, et al. 2004; Selvaraj, et al. 2004). It has also been used to indicate the degree of pollution or contamination or both. Data from samples taken from the control site was used to establish metal-normalizer relationships to which the data generated from various mechanic workshops are compared. According to this technique, metal concentrations were normalized to the textural characteristic of soils. Most commonly used reference elements include Sc, Mn, Al and Fe, (Loskaet al. 1997). In this study, Fe was chosen as the geochemical normalizer because of its conservative nature during diagenesis, (Chapman and Wang, 2001). Moreover, soils in Nigeria have been reported to be rich in Fe. Based on Rubio et al. (2000), EF is defined as:

$$
E F=\frac{\frac{X}{F e_{\text {soil }}}}{\frac{X}{F e_{\text {earthscrust }}}}
$$

Where $(\mathrm{X} / \mathrm{Fe})$ soil is the ratio of heavy metal $(\mathrm{X})$ to $\mathrm{Fe}$ in the soil from mechanic workshops, and $(\mathrm{X} / \mathrm{Fe})$ background is the natural background value of the Metal-Fe ratio.

\subsubsection{Contamination Factor}

Contamination factor $(\mathrm{CF})$ is given by the ratio of the pseudo-total level of the contaminant by the test soil sample to the level in the background sample and indicated on a contamination factor scale of 1-6 viz: CF < 1, low level of contamination, $1 \leq \mathrm{CF}<3$, moderate level of contamination, $3<\mathrm{CF}<6$, considerable level of contamination, and CF > 6, very high level of contamination (Hakanson, 1980; Anegbe et al. 2017).

\section{Cm Sample \\ Cm Background

Cm Sample $=$ metal concentration in Sample

$\mathrm{Cm}$ Background $=$ metal concentration in background or control Sample. (Lin et al. 2009)

\subsubsection{Contamination/Pollution Index}

Contamination/pollution (C/P) index provides assessment of the extent of enrichment of test soil/site above the target regulatory values and is given by the ratio of the level of the contaminant in the test soil sample to the target value,

\section{Concentration of metal in soil \\ $\mathrm{C} / \mathrm{PI}=\frac{\text { Target value from reference table }}{\text { Tom }}$

\subsubsection{Degree of Contamination}

The sum of contamination factors for all elements examined represents the contamination degree (CD) of the environment and four classes are recognized (Table10).

\subsubsection{Pollution Load Index (PLI)}

Generally, pollution load index (PLI) as reported by Harikumar et al. (2009), is as follows:

$\mathrm{PLI}=\sqrt[n]{C f 1 \times C f 2 x C f 3 x C f 4 \ldots \ldots \ldots \ldots \ldots C f n}$

Where, $\mathrm{CF}=$ contamination factor, $\mathrm{n}=$ number of metals

\subsection{Results and Discussion}

\subsection{Comparison of average total levels of heavy metals in soil samples of automobile workshops in Benin} City with levels in control soil sample

Comparison of the pseudo-total levels of heavy metals in contaminated soil with the levels in uncontaminated (control soil) may provide a first-tier indication of "enrichment" of heavy metals in contaminated soil. Though of limited value, a direct comparison of the levels of heavy metals in the control soil sample with the levels in soil samples from automobile workshops in Benin City is given in Table 1. 
Table 1:Comparison of Average Total Levels of Heavy Metals in Soil Samples from Automobile Workshops in Benin City with Levels in Control Soil Samples

\begin{tabular}{|c|c|}
\hline Location/Zone & $M_{\text {Total. }}\left(\mathrm{mg} \cdot \mathrm{kg}^{-1}\right)$ \\
\hline SE & 143.1 \\
\hline SW & 118.6 \\
\hline $\mathrm{NE}$ & 129.1 \\
\hline NW & 143.3 \\
\hline Control & 0.85 \\
\hline
\end{tabular}

These results show that the levels of heavy metals in soil samples from the automobile workshops were several orders of magnitude higher than the levels in the control soil sample, suggesting a deleterious impact of activities in automobile workshops on soil quality in Benin City.

\subsection{Comparison of Average Total Levels of Heavy Metals in Soil Samples Automobile Workshops in Benin} City with Target and Intervention Values

Two parameters have been defined by the local Environmental Regulatory Agencies for contaminated soil: the intervention value and the target value. Intervention values indicate the quality for which the functionality of soil for human, animal and plant lives is considered threatened by the contaminant. The values are related to soil properties: soil organic matter and clay contents and therefore site specific. The values may be obtained by using the relationship

$$
\mathrm{Ie}=\frac{\text { (Ist. A) }+(\text { B . \%clay })+\text { C.\%OM })}{A+25 B+10 \mathrm{C}}
$$

where $\mathrm{Ie}=$ intervention value $\left(\mathrm{mg} \cdot \mathrm{kg}^{-1}\right)$

Ist $=$ intervention value of standard soil $\left(\mathrm{mg} \cdot \mathrm{kg}^{-1}\right)$

$\%$ clay $=$ measured clay content of test soil sample

$\% \mathrm{OM}=$ measured organic content of test soil sample

$\mathrm{A}, \mathrm{B}$ and $\mathrm{C}$ are constants that depend on the metal contaminant

Target values $\left(\mathrm{M}_{\text {Target }}\right)$ indicate the soil quality with respect to a contaminant required for sustainability or expressed in terms of remedial policy, as the soil quality required for the full restoration of soil's functionality for human, animal and plant life. Target values are therefore the benchmark against which soil and/or site remediation endpoint may be compared and/or assessed.

Table 2: Comparison of Average Total Levels of Heavy Metals in Soil Samples from Automobile Workshops in Benin City with Target and Intervention Values.

\begin{tabular}{|c|c|c|c|c|c|c|}
\hline \multirow[t]{2}{*}{$\begin{array}{l}\text { Heavy } \\
\text { Metals }\end{array}$} & \multirow[t]{2}{*}{$\begin{array}{l}M_{(\text {Target }}{ }^{*} \\
\left(\mathrm{mg}^{\prime} \mathbf{k g}^{-1}\right)\end{array}$} & \multirow[t]{2}{*}{$\begin{array}{r}M_{(\text {Intervention })^{*}} \\
\left(\mathrm{mg}^{*} \mathrm{~kg}^{-1}\right)\end{array}$} & \multicolumn{4}{|c|}{$\begin{array}{l}\text { Average total levels of heavy metals in test soils } \\
\text { samples (mg.kg } \mathrm{kg}^{-1} \text { from automobile workshops }\end{array}$} \\
\hline & & & NW zone & SE zone & NE zone & SW zone \\
\hline $\mathrm{Cd}$ & 0.8 & 12 & 6.7 & 6.9 & 6.5 & 6.0 \\
\hline $\mathrm{Cr}$ & 100 & 380 & 49.0 & 49.0 & 40.80 & 37.70 \\
\hline $\mathrm{Ni}$ & 35 & 210 & 27.6 & 26.9 & 27.10 & 25.30 \\
\hline $\mathrm{Pb}$ & 85 & 530 & 28.1 & 26.7 & 25.60 & 24.10 \\
\hline
\end{tabular}

* Dutch Environmental Quality Standards.

The results given in table 2 compare the average total levels of the heavy metals in soil samples from automobile workshops in Benin City with the target and intervention values. It could be observed that all the heavy metals analyzed except cadmium have average total levels less than their target values, hence may be considered to present no environmental concern. It was also observed that all the individual metal analyzed in all the zones showed average total concentration that were below their intervention values. There was no target and intervention values for vanadium.

\subsection{Index of Geoaccumulation ( $\left.I_{g e o}\right)$}

As reported in table 3, this index consists of seven scales (0-6) ranging from unpolluted to very highly polluted. The interpretation of the results was made based on the scale above in comparison with control sample. 
Table 3: Geoaccumulation Indices for Sediment (Soil) Quality (Singh et al. 2003)

\begin{tabular}{|c|c|c|c|}
\hline Igeo & Class & \multicolumn{2}{|c|}{ Sediment (soil) quality } \\
\hline 0 & 0 & \multicolumn{2}{|c|}{ Unpolluted } \\
\hline $0-1$ & 1 & \multicolumn{2}{|c|}{ unpolluted to moderately polluted } \\
\hline $1-2$ & 2 & \multicolumn{2}{|c|}{ moderately polluted } \\
\hline $2-3$ & 3 & \multicolumn{2}{|c|}{ moderately-to-highly polluted } \\
\hline $3-4$ & 4 & \multicolumn{2}{|c|}{ highly polluted } \\
\hline $4-5$ & 5 & \multicolumn{2}{|c|}{ highly-to-very highly polluted } \\
\hline$>5$ & 6 & \multicolumn{2}{|c|}{ very highly polluted } \\
\hline \multicolumn{4}{|c|}{$\begin{array}{l}\text { From the } I_{\text {geo }} \text { values (Table } 4 \text { ), the soils in automobile workshops may be said to be highly to very highly } \\
\text { polluted, reflecting a higher degree of pollution than soils from the Ikhueniro open dump site in Benin (Ataikiru } \\
\text { and Okieimen, 2014). } \\
\text { Table 4: } \text { Igeo }_{\text {galues for Soil Samples from Automobile Workshops in Benin City }}\end{array}$} \\
\hline Zone of workshop & Heavy metals & Igeo values & Status of pollution \\
\hline \multirow[t]{5}{*}{ NW } & $\mathrm{Cd}$ & 6.10 & very highly polluted \\
\hline & $\mathrm{Cr}$ & 4.90 & highly-to-very highly polluted \\
\hline & $\mathrm{Pb}$ & 4.07 & highly-to-very highly polluted \\
\hline & $\mathrm{Ni}$ & 4.10 & highly-to-very highly polluted \\
\hline & $\mathrm{V}$ & 7.71 & very highly polluted \\
\hline \multirow[t]{5}{*}{$\mathrm{NE}$} & $\mathrm{Cd}$ & 6.07 & very highly polluted \\
\hline & $\mathrm{Cr}$ & 4.82 & highly-to-very highly polluted \\
\hline & $\mathrm{Pb}$ & 3.98 & highly polluted \\
\hline & $\mathrm{Ni}$ & 4.17 & highly-to-very highly polluted \\
\hline & $\mathrm{V}$ & 7.57 & very highly polluted \\
\hline \multirow[t]{5}{*}{ SW } & $\mathrm{Cd}$ & 5.99 & highly polluted \\
\hline & $\mathrm{Cr}$ & 4.70 & highly-to-very highly polluted \\
\hline & $\mathrm{Pb}$ & 3.92 & highly polluted \\
\hline & $\mathrm{Ni}$ & 4.06 & highly-to-very highly polluted \\
\hline & $\mathrm{V}$ & 7.44 & very highly polluted \\
\hline \multirow[t]{5}{*}{$\mathrm{SE}$} & $\mathrm{Cd}$ & 6.13 & very highly polluted \\
\hline & $\mathrm{Cr}$ & 5.00 & highly-to-very highly polluted \\
\hline & $\mathrm{Pb}$ & 4.01 & highly polluted \\
\hline & $\mathrm{Ni}$ & 4.12 & highly-to-very highly polluted \\
\hline & $\mathrm{V}$ & 7.71 & very highly polluted \\
\hline
\end{tabular}

\subsection{Environmental Risk Factor}

The environmental risk factor (ERF) is a pollution index used to determine environmental risk and establish potential threat of heavy metals organisms in the environment.

$\mathrm{ERF}<0 \quad=$ potential environmental threat

$\mathrm{ERF}>0 \quad=$ no potential environmental threat

Table 5:Environmental Risk Factors of Heavy Metals inSoils from Automobile Workshops in Benin City

\section{Heavy metal Zone/ERF values}

\begin{tabular}{ccccc} 
& NW & SE & NE & SW \\
\hline $\mathrm{Cd}$ & -3.02 & -2.76 & -2.55 & -2.77 \\
$\mathrm{Fe}$ & -3.18 & -2.33 & -3.59 & -3.56 \\
$\mathrm{~Pb}$ & -1.62 & -2.01 & -1.24 & -1.22 \\
$\mathrm{Ni}$ & -2.17 & -2.31 & -2.97 & -3.18 \\
$\mathrm{~V}$ & -2.68 & -2.92 & -3.57 & -3.31 \\
$\mathrm{Cr}$ & -2.53 & -2.97 & -3.81 & -2.80 \\
\hline
\end{tabular}

The ERF values obtained for soil samples from automobile workshops in Benin City (Table 5) are below 0 and indicate that the heavy metals in the soils samples from the automobile workshops present potential environmental threat.

\subsection{Enrichment Factor}

EF was used in the study to assess the relative contributions of natural and anthropogenic heavy metal inputs to soils (Adamo, et al. 2005).

The EF values close to unity indicates crusted origin, those less than 1.0 suggest a possible mobilization or depletion of metals, whereas EF $>1.0$ indicates that the element is of anthropogenic origin. 
Five contamination categories are recognized and interpreted as suggested by Birth (2003);

$\mathrm{EF}<1$ indicates no enrichment, $\mathrm{EF}<3$ is minor enrichment, $\mathrm{EF}=3-5$ is moderate enrichment, $\mathrm{EF}=5-10$ is moderately severe enrichment, $\mathrm{EF}=10-25$ is severe enrichment, $\mathrm{EF}=25-50$ is very severe enrichment and EF $>50$ is extremely severe enrichment. Details of the EF values of the metals studied in all the zones (NE, SE, NW and SW) with respect to the natural background concentration are presented in Table 6. Apart from Cd and $\mathrm{V}$ whose EF factors value were 0, i.e less than 1.0 suggesting a possible mobilization or depletion of metals, others $(\mathrm{Cr}, \mathrm{Pb}$ and $\mathrm{Ni})$ has $\mathrm{EF}>1.0$ clearly indicate that the elements are of anthropogenic origin.

In general, there was no much variation in the $\mathrm{EFs}$ of $\mathrm{Pb}, \mathrm{Cr}$ and $\mathrm{Ni}$ in all zones under investigation.

The enrichment factor of $\mathrm{Ni}, \mathrm{Pb}$ and $\mathrm{Cr}$ in all the zones as shown in table 6. 19-3.22 ranged from; minor enrichment to severe enrichment. $(\mathrm{EF}<3$ to $\mathrm{EF}=10-25)$. No site in all the zones recorded a value of $\mathrm{EF}=25-$ 50 and $\mathrm{EF}>50$ which means there is no case of very severe enrichment and extremely severe enrichment of metals in all the auto-mechanic workshops.

In a recent report, it has been shown that high EFs do not provide a reliable indication of the degree of human interference with the global environment (Sucharovà et al. 2012). In the report carried out in Czech Republic, where five different elements were used as reference, the sequence of the EFs do not reflect the relative importance of the elements determined. It was concluded that other factors such as the choice of reference element may be responsible for high EFs. The slight variation in EFs from site to site may also reflect the age of establishment of the various workshops and indicative of the number of services each workshops render.

Table 6: Enrichment Factor of Heavy Metals in Soil Samples from Automobile Workshops in Benin City

\begin{tabular}{|c|c|c|c|c|c|}
\hline \multirow{2}{*}{$\begin{array}{l}\text { Heavy } \\
\text { metals }\end{array}$} & \multirow[t]{2}{*}{ Crustal abundance* $\left(\mathrm{mg} \mathrm{kg}^{-1}\right)$} & \multicolumn{4}{|c|}{ Location of workshop/ Enrichment factor } \\
\hline & & NW & NE & SW & SE \\
\hline $\mathrm{Cd}$ & 0.15 & 18.72 & 18.16 & 16.76 & 19.27 \\
\hline $\mathrm{Cr}$ & 102 & 6.22 & 5.18 & 4.79 & 6.25 \\
\hline $\mathrm{Pb}$ & 14 & 2.45 & 2.23 & 2.10 & 2.33 \\
\hline $\mathrm{Ni}$ & 84 & 2.66 & 2.61 & 2.45 & 2.59 \\
\hline $\mathrm{V}$ & & 89.08 & 93.29 & 71.22 & 93.29 \\
\hline
\end{tabular}

*The crustal abundance of selected elements.

\subsection{Contamination Factor}

From the results of the contamination factors shown above, all the zones showed very high level of contamination with respect to all the heavy metals analyzed. This might be attributed to the very concentrations of the heavy metals in the automobile workshop sites compare to their respective concentrations in the control.

Table 7: Contamination Factors of the Heavy Metals from Automobile Workshops in Benin City

\begin{tabular}{lllll}
\hline Heavy metals & \multicolumn{4}{c}{ CF } \\
\cline { 2 - 5 } & NW & NE & SW & SE \\
\hline $\mathrm{Cd}$ & 670 & 650.00 & 600.00 & 690.00 \\
$\mathrm{Cr}$ & 222.73 & 185.45 & 171.36 & 223.64 \\
$\mathrm{~Pb}$ & 87.81 & 80.00 & 75.31 & 83.44 \\
$\mathrm{Ni}$ & 95.17 & 93.45 & 87.24 & 92.76 \\
$\mathrm{~V}$ & 3190.0 & 3340.0 & 2910 & 2550 \\
\hline
\end{tabular}

\subsection{Contamination/Pollution Index}

A distinction between soil contamination and pollution range was established by means of the contamination/pollution index C/PI (Table 8). C/P index values greater than unity (1) defines the pollution range, and when lowers than unity defines the contamination range. The standard employed for interpreting soil heavy metals contamination/pollution index varies from country to country based on the chosen factors (Lacatusu, 2000). 
Table 8: C/PI Significance

\begin{tabular}{|c|c|}
\hline $\mathbf{C} / \mathbf{P I}$ & Significance \\
\hline$<0.1$ & Very slight contamination \\
\hline $0.10-0.25$ & Slight contamination \\
\hline $0.26-0.50$ & Moderate contamination \\
\hline $0.51-0.75$ & Severe contamination \\
\hline $0.76-1.00$ & Very severe contamination \\
\hline $1.10-2.00$ & Slight pollution \\
\hline $2.10-4.00$ & Moderate pollution \\
\hline $4.10-8.00$ & Severe pollution \\
\hline $8.10-16.00$ & Very severe pollution \\
\hline$>16.00$ & Excessive pollution \\
\hline
\end{tabular}

Table 9: C/P Index of the Heavy Metals from Automobile Workshops in Benin City

\begin{tabular}{lllll}
\hline Heavy metals & \multicolumn{5}{c}{ C/P index } \\
\cline { 2 - 5 } & NW & NE & SW & SE \\
\hline $\mathrm{Cd}$ & 8.38 & 8.13 & 7.50 & 8.63 \\
$\mathrm{Cr}$ & 0.49 & 0.41 & 0.38 & 0.49 \\
$\mathrm{~Pb}$ & 0.33 & 0.30 & 0.28 & 0.31 \\
$\mathrm{Ni}$ & 0.79 & 0.77 & 0.72 & 0.77 \\
$\mathrm{~V}$ & - & - & - & - \\
\hline
\end{tabular}

Table 10: Classes of Contamination Degree (CD) (Hakanson, 1980).

\begin{tabular}{|l|l|}
\hline Classes & Contamination Degree (CD) \\
\hline $\mathrm{Cdeg}<8$ & Low degree of contamination \\
\hline $8<\mathrm{Cdeg}<16$ & Moderate degree of contamination \\
\hline $16<\mathrm{Cdeg}<32$ & Considerable degree of contamination \\
\hline $\mathrm{Cdeg}>32$ & Very high degree of contamination \\
\hline
\end{tabular}

The values of the $\mathrm{C} / \mathrm{P}$ index of the heavy metals from automobile workshops in Benin City are given in Table 9. Using the C/P index, the soil samples may be classified as moderately contaminated with respect to $\mathrm{Pb}$ and $\mathrm{Cr}$ in all the zones, very severely contaminated with respect to $\mathrm{Ni}$ in all zones except in SW zone where it showed severe contamination, and Very severely polluted with respect to Cd in all the zones except in SW zone where it showed severe pollution.

\subsection{Degree of Contamination}

The contamination factor described in Table 7 is a single element index. The sums of contamination factors for all the metals examined are listed in Table11.

Using the sum of contamination factors obtained in Table7 for all elements in each zone, the contamination degree (CD) for each zone is therefore calculated as shown in Table 11 below: From Table 11, the degree of contamination (CD) values for all the zones are greater than 32 . Hence, the soils in the vicinity of the automobile workshops in all the zones are therefore classified as having very high degree of contamination. However, it is worthy of note that soil samples from NE zone has the highest degree of contamination compare to other zones. The highest degree of contamination observed in the NE zone may be attributed to the large size and old age of many of automobile workshops in the zone coupled with the location of the zone within Benin City metropolis, and high volume of wastes deposited at those workshops found within the zone.

\subsection{Pollution Load Index (PLI)}

PLI provides a rather simple means of assessing soil/site quality.

The PLI value of $>1$ is polluted, whereas $<1$ indicates no pollution (Harikumar et al. 2009).

Table 11:Contamination Degree and Pollution Load Index ofHeavy Metals inSoil Samples from Automobile Workshops in Benin City

\begin{tabular}{lll}
\hline Location of Automobile workshop & CD & PLI \\
\hline NW & 4265.71 & 331.08 \\
NE & 4348.90 & 313.12 \\
SW & 3843.91 & 287.54 \\
SE & 3639.84 & 313.86 \\
\hline
\end{tabular}

The pollution load index values as calculated for automobile workshops in all zones were far greater than 1 (Table 11). This is an indication that the soil samples from all zones were severely polluted by the heavy metals. 


\subsection{Conclusion}

The anthropogenic contamination status of soil from automobile workshops has been evaluated using various pollution indices and the results are in agreement in suggesting that the test soil samples are severely contaminated by heavy metals; and that automobile workshops are active point-sources for the dispersal of heavy metals into soil in Benin City.

\subsection{References}

Adamo, P., Arienzo, M., Imperato, M., Naimo, D., Nardi, G. and Stanzione, D. (2005), Distribution and Partition of Heavy Metals in Surface and Sub-Surface Sediments of Naples City Port. Chemosphere, 61:800-809.

Anegbe B., Okuo J.M., Atenaga M., Ighodaro A., Emina A., Oladejo N.A. (2018). Distribution and Speciation of Heavy Metals in Soils around Some Selected Auto Repair Workshops in Oghara, Delta State, Nigeria.International Journal of Environment, Agriculture and Biotechnology (IJEAB) 3(2): 574-584.

Ataikiru, H.O. and Okieimen, F.E. (2014), Environmental Risk Assessment of Heavy Metals in Soils in the Vicinity of Open Dump Sites in Warri, 86pp.

Bentum J. K., Anang M., Boadu K. O., Koranteng- Addo E. J. and Owusu A. E. (2011), Assessment of Heavy Metals Pollution of Sediments from Fosu Lagoon in Ghana Bull. Chem. Soc. Ethiop., 25(2), 191-196.

Chapman, P.M. and Wang, F. (2001), Assessing Sediment Contamination in Estuaries. Environmental Toxicology and Chemistry, 20: 3-22.

Department of Petroleum Resources (2002), Environmental guidelines and Standards for the petroleum industries in Nigeria Department of Petroleum Resources, Ministry of Petroleum and Mineral Resources, Abuja, Nigeria. Environmental Geology 39, 90-98.

Gimmler, H., Carandang, J., Boots, A., Reisberg, E. and Woitke, M. (2002), Heavy metalcontent and distribution within a woody plant during and after seven years continuousgrowth on municipal solid waste (MSW) bottom slag rich in heavy metals. Applied Botany, 76: 203-217.

Gothberg, A., Greger, M., Holm, K. and Bengtsson, B. (2004), Influence of nutrients on uptakeand effects of $\mathrm{Hg}$, $\mathrm{Cd}$ and $\mathrm{Pb}$ in Ipo-moea aquatica. Journal of Environmental Quality,33: 1247-1255.

Hakanson L. (1980), Ecological risk index for aquatic pollution control, a sedimentological approach. Water resources, 14; 975-1001.

Harikumar P. S., Nasir U. P. and Mujeebu Rahma M. P. (2009), Distribution of heavy metals in the core sediments of a tropical wetland system; International Journal of Environmental Science and Technology, vol. 6, pp. 225-232.

Khodadoust, A. P., Reddy, K. R. and Maturi, K. (2005), Removal of nickel and phenanthrene from kaolin soil using different extractants, Environmental Engineering Science, 21(6): 691-704.

Lacatusu, R. (2000), Appraising levels of soil contamination and pollution with heavy metals in Heinike H. J., Eckselman W., Thomasson A.J., Jones R.J.A, Montanarella L. and Buckeley B.(eds.). Land information systems for planning the sustainable use of land resources. EuropeanSoil Bureau Research Report No. 4. Office of Official Publication of the European Communities, Luxembourg, pp 393-402.

Lin, J., Cai, M., Qi, A. and Hu, H. (2009), Contamination level and Speciation of Heavy Metals in Sediments from Yundang Lake, Xiamen. ICECS Second International Conference on Environmental and Computer Science, 28-30 December, Pp 48-52.

Lin, Q., Wang, Z.W., Ma, M. and Chen, Y.X. (2006), Evaluation of dissipation mechanisms by Lolium perenne $\mathrm{L}$, and Raphanus sativus for pentachlorophenol (PCP) in copper co-contaminated soil. Science of Total Environment,368:814-822.

Loska, K., Cebula, J., Pelczar, J., Wiechuła, D. and Kwapuliński, J. (1997), Use of Enrichment, and Contamination Factors Together with Geoaccumulation Indexes to Evaluate the Content of $\mathrm{Cd}, \mathrm{Cu}$, and $\mathrm{Ni}$ in the Rybnik Water Reservoir in Poland. Water, Air, and Soil Pollution, 93: 347-365.

Martin, T.A. and Ruby, M.V. (2004), Review of in situ remediation technologies for lead, zinc and cadmium in soil. Remediation, 14-32.

Mohanty B. and Mahindrakar A. B. (2011), Removal of Heavy Metal by ScreeningFollowed by Soil Washing from Contaminated Soil. International Journal of Technology and Engineering System(IJTES): Vol.2. No.3, 290-293.

Nwaka, P.O. Anegbe, B., Adeniyi, O., Okunzuwa, I.G. and Jidonwo, A. (2018), Impact of Hospital Waste on the Physico-chemical Properties of Soil from Medical Waste Dumpsite in Oghara, Delta State Nigeria. Physical Science International Journal.17(1): 1-14.

Oladejo N.A., Anegbe, B. and Adeniyi, O. (2017), Accumulation of Heavy Metals in Soil and Maize Plant (Zea mays) in the Vicinity of Two Government Approved Dumpsites in Benin City, Nigeria. Asian Journal of Chemical Sciences3(3): 1-9.

Reddy, M.S., Basha, S., Kumar, V.G.S., Joshi, H.V. and Ramachandraiah, G. (2004), Distribution, Enrichment and Accumulation of Heavy Metals in Coastal Sediments of Alang-Sosiya Ship Scrapping Yard, India. 
Marine Pollution Bulletin.48: 1055-1059.

Rubio, B., Nombela, M.A. and Vilas, F. (2000), Geochemistry of Major and Trace Elements in Sediments of the Ria deVigo (NW Spain): An Assessment of Metal Pollution. Marine Pollution Bulletin, 40: 968-980.

Saenz, M., Blasco, J. and Gomez-Parra, A. (2003), Speciation of heavy metals in sediments of three coastal ecosystems in the Gulf of Cadiz, southwest Iberian Peninsula. Environmental Toxicology and Chemistry, 22(12): 33-39.

Selvaraj, K., Mohan, V.R. and Szefer, P. (2004), Evaluation of Metal Contamination in Coastal Sediments of the Bay of Bengal, India: Geochemical and Statistical Approaches. Marine Pollution Bulletin, 49: 174-185.

Singh, A. K., Hasnain, S. I. and Benerjee, D. K., (2003), Grain Size and Geochemical Portioning of Heavy Metals in Sediments of the Damodar River.A Tributary of the Lower Gang, India.

Sucharovà, J., Suchara, I., Hola, M., Marikova, S., Reimann, C., Boyd, R., Filzmoser, P. and Englmaier, P. (2012), Top-/Bottom-Soil Ratios and Enrichment Factors: What Do They Really Show? Applied Geochemistry, 27:138-145.

Tijani, M.N., Onodera S. and Adeleye, M. A. (2005), "Environmental implications of adsorbed and total trace metals concentrations in bottom-sediments of an urban drainage network in a developing country", Materials and Geoenvironment, Vol. 52, No. 1, pp. 127-130.

Vangronsveld, J., Herzig, R., Weyens, N., Boulet, I., Adriaesen, K., Ruttens, A., Thewys, T., Vassilev, A., Meers, E., Nehnesayva, E., van der Lie, D. and Mench, M. (2009), Phytoremediation of contaminated soil and groundwater. Lessons from the field. Environmental Sciences and Pollution Research, 16: 765-794.

Woitke, P., Wellmitz, J., Helm, D., Kube, P., Lepom, P. and Litheraty, P. (2003), Analysis and Assessment of Heavy Metal Pollution in Suspended Solids and Sediments of the River Danube. Chemosphere, 51: 633-642. 